\title{
Autism spectrum disorder and parental conceiving age
}

\author{
Andrea Abadi, ' Francisco R. de la Peña ${ }^{2}$
}

Dirección del Departamento Infanto Juvenil, Grupo INECO; Coordinación del Área de Neurodesarrollo y CEA-CITES INECO; Universidad Favaloro, Ciudad Autónoma de Buenos Aires, Argentina.

2 Unidad de Fomento a la Investigación, Dirección de Servicios Clínicos, Instituto Nacional de Pisquiatría Ramón de la Fuente Muñiz, Ciudad de México, México.

Correspondence:

Francisco R. de la Peña

Unidad de Fomento a la lnvestigación

Dirección de Servicios Clínicos,

Instituto Nacional de Pisquiatría

Ramón de la Fuente Muñiz.

Calz. México-Xochimilco 101

Col. San Lorenzo Huipulco,

Alcaldía Tlalpan, C.P. 14370

Ciudad de México, México.

Phone: (55) 4160 - 5305

Email: adolesc@imp.edu.mx

Citation:

Abadil, A., \& de la Peña, F. R.

(2020). Autism spectrum disorder and parental conceiving age. Salud Mental, 43(3), 101-103

DOI: $10.17711 /$ SM.0185-3325.2020.014
Autism spectrum disorder (ASD) is a highly prevalent condition worldwide. Data from epidemiological studies show an estimated median prevalence of 62 per 10000 people, with a homogeneous distribution across ethnic and socioeconomic groups (Elsabbagh et al., 2012) outside the United States of America (USA) (Durkins et al., 2017). ASD account for a substantial health loss across the lifespan. Globally, autistic disorders accounted for more than 58 DALYs per 100000 population (Baxter et al., 2015). For instance, in Guanajuato, Mexico, the prevalence of ASD is .87\% (Fombonne et al., 2016). ASD is a neurodevelopment disorder, which also includes attention deficit hyperactivity disorder (ADHD), intellectual disability, communication disorders, learning disorders, tic disorders, all of them included in the Diagnostic and Statistical Manual for Mental Disorders in its fifth edition (DSM-5), (American Psychiatry Association, 2013). ASD is characterized by a significant limitation in social interaction and communication, as well as by the presence of repetitive behaviors and restricted and stereotyped behaviors (American Psychiatric Association, 2013). The broadest phenotype, not restricted to DSM-5, has four latent classes in preschool children: mild language delay with cognitive rigidity; mild language and motor delay with dysregulation, general developmental delay; and significant developmental delay with repetitive motors behaviors (Wiggins el al., 2017).

There are several researches approaching ASD etiology, like genetic aspects (Torrico et al., 2016; Davis, Heft, Scherer, \& Sikela, 2019), immunological conditions (Goines \& Van de Water, 2010), hormonal regulation (Baron-Cohen et al., 2015), and environmental situations (Shelton et al., 2014). However, its precise origin is unknown, but a multifactorial scheme is plausible.

Some research lines have focused on studying assisted conception (artificial insemination, ovulatory induction, in vitro fertilization, embryo transfer) as an element associated with the etiology of ASD. So the question arises: How do assisted conception techniques influence the development of ASD?

Without doubt, studies on birth registration carried out in Denmark are very helpful in understanding the role of assisted conception. One of them followed up in 2008 children born in the period from 1995 to 2003 . Out from a total of 555828 births, 3394 (.61\%) children with ASD were reported. Children born by assisted conception have a hazard rate ratio increased for ASD from $1.25 \%$ to $1.43 \%$ (Hvidtjørn et al., 2011). Another study with the same population but a follow-up to 2012 compared the psychopathology of the 33139 children born under assisted conception versus the 522689 children conceived naturally. Only children conceived with ovulatory induction with or without artificial insemination had an increased hazard rate ratio of $4.1 \%$ for any mental disorder, $1.5 \%$ for ASD, $1.7 \%$ for ADHD, and $.8 \%$ for any behavioral or emotional disorder (Bay, Mortensen, Hvidtjørn \& Kesmodel, 2013).

Both male and female infertility are the most frequent factors leading couples to seek assisted conception. Pathologies of the reproductive system, both in women and men, are some of the most frequent causes of infertility. A study that gathered information from several states in the USA showed that maternal infertility, as an independent finding, increases the risk of ASD in children, not in a first pregnancy, but in later conceptions (Schieve et al., 2017).

The second factor to consider is the age of those who attend assisted conception treatment. Nowadays, the personal and professional fulfillment postpone the search for children 
in new families. Then, after trying to conceive naturally for several years, they seek medical support for fertilization, even after the fourth decade of life, which is a factor that increases the prevalence rate of ASD (Parner et al., 2012). Both female and male gametes get old as the individual grows, with the associated risks of de novo mutations.

An interesting meta-analysis that included 25687 ASD cases and 8655576 control subjects, found that mothers over 35 years of age compared to mothers between 25 to 29 years of age presented a relative risk of 1.52 to procreate children with ASD (Sandin et al., 2012).

This analysis would be incomplete if the age of the male parent is left out, because spontaneous mutations in sperm DNA increase as the individual ages, so the risk of transmitting material with mutations is highly probable. ASD children relative risk from fathers between 40 to 45 years compared to those under 32 years has been reported as 1.75, however the risk of children with ASD associated with paternal age was evident with mothers under 35 years. In contrast, the risk of advanced maternal age increases regardless of fathers age, so it can be concluded that the older age of mothers has greater implications for the risk of having children with ASD than the age of fathers (Idring et al., 2014).

For more than 30 years, Salud Mental journal has had a serious commitment to the dissemination of ASD reviews and investigations. The journal has published several papers on the etiological aspects related to autism (León Andrade \& Ortega, 1985; Gomez, Camarena \& Nicolini, 1997), about the disease's history (Garrabé, 2012; Nicolini, 2018), and difficulties in evaluation and diagnosis (Albores-Gallo, Hernández-Guzmán, Díaz-Pichardo, \& Cortés Hernández, 2008), as well as the appropriate tools for its recognition (Zavaleta-Ramírez, Náfate-López, Villareal-Valdés, UlloaFlores, \& Albores-Gallo, 2014).

In the current number, a research carried out in Mexico City is published. This investigation was developed as a collaborative work of the Hospital Psiquiátrico Infantil Juan N. Navarro, the Universidad Nacional Autónoma de México, the Asociación Mexicana de Niños con TDAH and the Instituto Nacional de Medicina Genómica. The article evaluates the parents' age of 1068 children between 18 and 72 months of age, with a given ratio of three boys for each girl; of them 162 presented ASD and 906 did not. All of them were evaluated between March 2014 and November 2016. In both groups parental age was analyzed, and the results were interesting since the parents of children with ASD were older than parents of children without ASD (31.54 SD \pm 8.67 versus $29.17 S D \pm 8.67 ; p<.001$ ), presenting an increased risk of 1.04. The most surprising finding was that only parents between 40 to 49 years of age had a 2.57 risk for having children with ASD. Another interesting fact was an increased risk for children to develop ASD when the age difference between the mother and the father was greater than 10 years. Unlike other studies, maternal age did not an influence for an increased risk.

In summary, much remains to be discovered and investigated around the risk factors for the development of ASD on conception and parental age. However, there is increasing data to understand ASD origins. The study of this disorder must remain a priority for the next decade not only in Mexico but in all Latin America (de la Peña, Bernal-Santamaría, \& Villalobos-Montero, 2019).

\section{Aknowledgments}

To Jordan Villalobos-Montero for his participation in updating epidemilogical data and in the last English version.

\section{REFERENCES}

Albores-Gallo, L., Hernández-Guzmán, L., Díaz-Pichardo, J. A., \& CortésHernández, B. (2008). Dificultades en la evaluación y diagnóstico del autismo. Una discusión. Salud Mental, 31(1), 37-44.

American Psychiatric Association. (2013). Diagnostic and statistical manual of mental disorders: DSM-5. (5th ed.). Washington, DC: American Psychiatric Press.

Baron-Cohen, S., Auyeung, B., Nørgaard-Pedersen, B., Hougaard, D. M., Abdallah, M. W., Melgaard, L., ... Lombardo, M. V. (2015). Elevated fetal steroidogenic activity in autism. Molecular Psychiatry, 20(3), 369-376.

Baxter, A. J., Brugha, T. S., Erskine, H. E., Scheurer, R. W., Vos, T., \& Scott, J, G. (2015). The epidemiology and global burden of autism spectrum disorders. Psychological Medicine, 45(3), 601-613. doi: 10.1017/S003329171400172X

Bay, B., Mortensen, E. L., Hvidtjørn, D., \& Kesmodel, U. S. (2013). Fertility treatment and risk of childhood and adolescent mental disorders: register based cohort study. British Medical Journal, 347(f3978), 1-11. doi: 10.1136/bmj.f3978

Davis, J. M., Heft, I., Scherer, S. W., \& Sikela, J. M. (2019). A third linear association between Olduvai (DUF1220) Copy Number and severity of the classic symptoms of inherited Autism. American Journal of Psychiatry, 176(8), 643650. doi: 10.1176/appi.ajp.2018.18080993

Durkin, M. S., Maenner, M. J., Baio, J., Christensen, D., Daniels, J., Fitzgerald, R., ... Yeargin-Allsopp, M. (2017). Autism Spectrum Disorder Among US Children (2002-2010): Socioeconomic, Racial, and Ethnic Disparities. American Journal of Public Health, 107(11), 1818-1826. doi: 10.2105/AJPH.2017.304032

Elsabbagh, M., Divan, G., Koh, Y. J., Kim, Y. S., Kauchali, S., Marcín, C., ... Yasamy, M. T. (2012). Global prevalence of autism and other pervasive developmental disorders. Autism Research, 5(3), 160-179. doi: 10.1002/aur.239

Fombonne, E., Marcin, C., Manero, A. C., Bruno, R., Diaz, C., Villalobos, M., ... Nealy, B. (2016). Prevalence of Autism Spectrum Disorders in Guanajuato, Mexico: The Leon survey. Journal of Autism and Developmental Disorders, 46(5), 1669-1685. doi: 10.1007/s10803-016-2696-6

Garrabé, J. (2012). El autismo. Historia y clasificaciones. Salud Mental, 35(3), $257-$ 261.

Goines, P., \& Van de Water, J. (2010). The immune system's role in the biology of autism. Current Opinion in Neurology, 23(2), 111-117. doi: 10.1097/ wco.0b013e3283373514

Gomez, A., Camarena, B., Nicolini, H. (1997). Investigación sobre algunos de los factores genéticos y cognoscitivos que influyen en la etiología del autismo. Salud Mental, 20(1), 50-55.

Hvidtjørn, D., Grove, J., Schendel, D., Schieve, L. A., Sværke, C., Ernst, E., \& Thorsen, P. (2011). Risk of autism spectrum disorders in children born after assisted conception: a population-based follow-up study. Journal of Epidemiology \& Community Health, 65(6), 497-502. doi: 10.1136/jech.2009.093823

Idring, S., Magnusson, C., Lundberg, M., Ek, M., Rai, D., Svensson, A., ... Lee, B. (2014). Parental age and the risk of autism spectrum disorders: findings from a Swedish population-based cohort. International Journal of Epidemiology, 43(1), 107-115. doi: 10.1093/ije/dyt262 
León Andrade, C., \& Ortega, H. (1985). Autismo: Aspectos Biológicos. Salud Mental, 8(3), 33-40.

Nicolini, H. (2018). Autismo, la patología del momento en la psiquiatría. Salud Mental, 41(3), 105-107. doi: 10.17711/SM.0185-3325.2018.022

Parner, E. T., Baron-Cohen, S., Lauritsen, M. B., Jørgensen, M., Schieve, L. A., Yeargin-Allsopp, M., \& Obel, C. (2012). Parental age and autism spectrum disorders. Annals of Epidemiology, 22(3), 143-150. doi: 10.1016/j. annepidem.2011.12.006

de la Peña, F. R., Bernal-Santamaría, N., \& Villalobos-Montero, J. N. (2019). Priorities in psychiatry for the next decade: Challenges for research. Salud Mental, 42(6), 259-260. doi: 10.17711/sm.0185-3325.2019.033

Sandin, S., Hultman, C., Kolevzon, A., Gross, R., MacCabe, J., \& Reichenberg, A. (2012). Advancing Maternal Age Is Associated with Increasing Risk for Autism: A Review and Meta-Analysis. Journal of the American Academy of Child \& Adolescent Psychiatry, 51(5), 477-486. doi: 10.1016/j.jaac.2012.02.018

Schieve, L., Drews-Botsch, C., Harris, S., Newschaffer, C., Daniels, J., DiGuiseppi, C., ... Windham, C. (2017). Maternal and Paternal Infertility Disorders and Treatments and Autism Spectrum Disorder: Findings from the Study to Explore Early Development. Journal of Autism and Developmental Disorders, 47(12), 3994-4005. doi: 10.1007/s10803-017-3283-1
Shelton, J. F., Geraghty, E. M., Tancredi, D. J., Delwiche, L. D., Schmidt, R. J., Ritz, B., ... Hertz-Piccioto, I. (2014). Neurodevelopmental Disorders and Prenatal Residential Proximity to Agricultural Pesticides: The CHARGE Study. Environmental Health Perspectives, 122(10), 1103-1109. doi: 10.1289/ ehp. 1307044

Torrico, B., Chiocchetti, A. G., Bacchelli, E., Trabetti, E., Hervás, A., Franke, B., ... Toma, C. (2016). Lack of replication of previous autism spectrum disorder GWAS hits in European populations. Autism Research, 10(2), 202-211. doi: 10.1002/aur.1662

Wiggins, L. D., Tian, L. H., Levy, S. E., Rice, C., Lee, L., Schieve, L., ... Thompson, W. (2017). Homogeneous Subgroups of Young Children with Autism Improve Phenotypic Characterization in the Study to Explore Early Development. Journal of Autism and Developmental Disorders, 47, 3634-3645. doi: 10.1007/ s10803-017-3280-4

Zavaleta-Ramírez, P., Náfate-López, O., Villareal-Valdés, G., Ulloa-Flores, R. E., \& Albores-Gallo, L. (2014). Confiabilidad interevaluador del K-SADS-PL-2009/ trastornos del espectro autista (TEA). Salud Mental, 37(6), 461-466. 